\title{
Inquiry into the Position of Object of Network Education for Physical Education
}

\author{
Jiang Huabei \\ Wushu Department \\ Hebei Sport University \\ Shijiazhuang, China \\ 714332974@qq.com
}

\author{
Ma Zhenlei \\ Wushu Department \\ Hebei Sport University \\ Shijiazhuang, China \\ 516210920@qq.com
}

\author{
$\mathrm{Xu}$ Hailong \\ Wushu Department \\ Hebei Sport University \\ Shijiazhuang, China \\ xuhailonghebei@yahoo.com.cn
}

\begin{abstract}
Starting with the characteristic of the network education and learning environment, the essential condition of network learners and the nature of school physical education, this article discusses the question to position the object of network education for physical education object, and presents the view that object of network education for physical education shall be positioned as the non-degree education to the in-service gym teachers graduated from sports colleges and universities (or with equivalent qualification) meets the requirement of network education, physical education and the rules about network education object proposed by the Ministry of Education.
\end{abstract}

KeyWords-Network Education; Position; Tacit; Learning Environment

\section{INTRODUCTION}

Since the Ministry of Education approved of Tsinghua University's and 3 other general universities' carrying out modern distance education (network education) as the first group of experimental units in March, 1993, network education (in narrow sense) of our country has been developing rapidly. The construction of network education has been an important part of construction of all subjects. Compared with the other subjects, the state quo of network education for physical education construction is not very optimistic. But, it is certain that network education for physical education will develop rapidly in the future because network education is the reform trend and direction of modern education. Now, some sports colleges and universities in our country, especially the College of Sports Science of South China Normal University which has done many jobs about network education and acquired series of achievements, are researching and developing network education for physical education.

Starting with the nature of network education and learning environment, the essential condition of network learners and the nature of school physical education, this article discusses the question to position the object of network education for physical education. I hope this article can offer some suggestions for network education for physical education in our country at the initial developing stage so that we can avoid paying for the cost of unclear network education object position like other subjects.

\section{RESEARCH METHODS}

\section{A. Documentary Method}

By reaching the articles about network education in recent years and systematically studying monographs like Network Education, Modern Distance Education and so on, I have gotten systematic understanding about the state quo of network education and network education for physical education in our country, and established the theoretical foundation for researching position of object of network education for physical education.

\section{B. Expert Interviewing Method}

By interviewing the experts of physical education, distance education, education and psychology, I have deeply understood the essential condition of network learners and the relevant policies about network education proposed by the Ministry of Education.

\section{Comparative Analyzing Method}

According to the comparative analysis about subject nature of physical education and other subjects, I have gotten the conclusion that physical education is the practice course which takes physical exercise as the main content, and found out the object which is fit for network education for physical education.

\section{ANALYSIS AND DISCUSSION}

\section{A. Characteristic of Network Education and Learning Environment}

The characteristic of network education is separation of time and space between teachers and learners. They are separated in virtual learning environment of different time rather than staying in the same physical learning environment, which means the traditional face to face teaching of same time, space and synchronization has been changed to the network education of different time, space and asynchronization. The collective formed under network learning environment would be virtual, loose and totally different from class or school in our real life.

The collective in our real life has great effect to individuals, for example, collective gives individuals security; the individuals of collective cooperate and compete with each other; collective has opinion and disciplining effect to words and deeds of individuals, etc. The collective 
on internet doesn't have these effects to individuals, and thus it would cause some changes in students' psychology. Undergraduate students with foundation of senior middle school is at developing stage of physiology and psychology which are not matured enough to adapt to these changes. So, undergraduate students with foundation of senior middle school shall not be the main network education object.

The education purpose is to train successors of socialism construction with comprehensive development of morality, intelligence and physique. Undergraduate students with foundation of senior middle school have already been adults from the angle of physiology, but they have not been the real adults from the angle of sociology. They have many things to learn, especially morality. As it is said, before one learns knowledge, he has to learn to be a virtuous person. But unfortunately, education under the network learning environment doesn't have this effect. In traditional education, we can carry out moral education in different way, such as teachers' actions or sight which would affect students. But, teachers' words and deeds in network education do not have this effect.

\section{B. The Essential Condition of Network learners}

Network education is a new teaching environment which: realizes individualized teaching, independent studying and development of innovative thinking ability; creates the interactive and flexible situation, and realizes widely interpersonal communication, cooperation and supports intelligence interaction; creates virtual learning environment which provides learners more space of creation and freedom of practice. So, network education environment has high requirement on learners. General speaking, the network education which mainly focuses on learners' independent studying requires the right learning view, strong self-learning ability and perseverance of learners.

\section{1) Learning View}

The coming of knowledge economy and learning-based society has changed people's traditional view on education. The view of lifelong learning has been deeply rooted among the people. Network education develops with this trend, idea and need, so the nature of network education is the independent study emphasizing individual whose learning view is not "make me learn" of passiveness but "I want to learn" of activeness. So, we can say that the change of selflearning view of network learners is acting an important role during the while learning process.

The network learners with foundation of senior middle school who were under pressure of college entrance examination and teachers' strict requirement are accustomed to the strong pressure and requirement from outside because of the long-term learning experience of exam-oriented education. They don't have the right purpose and learning view, that's why they are different from the in-service adults whose learning obviously has purpose of occupation, interest or hobby. At the beginning of learning, the inservice adults' learning excitement is focused on the close connection between the knowledge they learn and the real work. They find, analyze and solve the practical problem by using the knowledge they learnt. They decide the research subject and make research plan so that they can apply the learning to practical problems and be the master of learning who change "make me learn" to "I want to learn".

2) Self-learning Ability

Under the network environment, the learners don't have teachers around, and have to learn under self-control. So, network education requires strong self-learning ability of learner. The self-learning ability we said here means the ability of self-plan, self-adapt, self-control, selecting learning content by self, self-assessment, and others during the learning process according to the change of learning environment.

During the learning process, not only do learners have to plan their learning sequence and schedule according to their physiological and psychological characteristics and the environmental condition, they have to restructure and complete their knowledge according to their direction and knowledge base in order to meet social requirement and develop themselves. The vast learning resource on internet would make learners be lost, and teachers can not always stay online to guide learners. So the learners' ability of identification and selection are required so that they will not be puzzled about how to start with the vast of learning content or accept them all. During the learning process, network learners would encounter the problems like how to resist temptation of all forms on internet by self-control, and thus it requires learners to restrain their desire, deed and resist external disturbance. Learners shall assess and summarize their learning effects at every learning stage to adjust learning plan, learning content, etc.

\section{3) Learning Perseverance}

Compared with traditional education, network education has many advantages which traditional can not match. But, network education still can not replace traditional teaching because of the face to face communication and interaction between students and teachers. Learners are always facing to the screen without interaction, including hand gesture, expression, body language and others between students and teachers of traditional education. So, learners, especially the undergraduate students with foundation of senior middle school who don't have clear learning purpose or learning motivation, would feel boring and tired during the learning process, and thus they can not learn continually. So, network education requires learners to be comparatively mature in age and psychology and to have good ability of selfdiscipline and firm confidence to realize learning purpose.

Analyzed essential condition of network learners, it is not difficult to see that network education does not fit for undergraduate students with foundation of senior middle school. The in-service adults who are comparatively mature in physiology and psychology are fit for network education because of their clear learning purpose, powerful pertinence, strong self-learning ability and perseverance.

\section{Nature of College Physical Education}

According to the analysis about nature of Physical Education based on the theory of tacit knowledge, network education does not fit for undergraduate students with 
foundation of senior middle school. On one side, undergraduate students with foundation of senior middle school have never taken specialized technical training, so there are many sports techniques they can't understand. Although they can learn the sport technique through the sport technique and method explained in words, their skilled movement would be quite different and can not match the rationalized and standardized skilled movements we require because of the difference of factors like comprehensive ability, knowledge level, etc; on the other hand, considering the tacit knowledge of physical education, a special form of knowledge, we should pay attention to tacit knowledge or not focus too much on the knowledge explained in words during the process of assessing physical education curriculum which obviously does not fit for the undergraduate students with foundation of senior middle school. So, network education for physical education in our country is not fit for degree education of undergraduate students with foundation of senior middle school, and we shall carry out non-degree education to the in-service staffs who graduated from sports colleges and universities.

Beside nature of physical education, we should analyze it from teaching practice. If we carry out network education to them, and make them watch outstanding athletes' skilled movement on internet for many times before they take exercise, they would probably forget what they have watched or even the movements they remember are completely different when they are ready for exercise on playground. That is not the learning effect we need. Time and again, students' initiative would be spoiled.

\section{CONCLUSIONS}

A. Object of network education for physical education shall be positioned as the non-degree education to in-service gym teachers who graduated from sports colleges and universities (or with equivalent qualification). And thus, learners' individuation, problem, pertinence, otherness and other learning requirements would be met, and learners will control the whole learning process. Meaning while, our object position meets the rules about college of network education stops admitting learners without foundation proposed by the Ministry of Education.

$B$. From the view of characteristic of network learning environment, network education can not carry out allaround education, especially moral education, to undergraduate students with foundation of senior middle school, and thus it is not good for learners' physical and psychological development.

C. $\quad$ Network learners need right learning view, strong self-learning ability and perseverance to adapt to the network education environment and gain good effect. Network learners with foundation of senior middle school don't have those conditions, so they are not fit for network education.

\section{REFERENCES}

[1] Li Yiyuan, Investigation about Demand and Construction State of College Excellent Course Network Resource Development [J]. Network Education, 2009, (12)

[2] Wang Wencheng, Meng Zhaoli and Tian Aihua, Problems and Thinking in General College and University Excellent Course Construction [J]. Journal of Beijing Sport University, 2008, (03)

[3] Chen Dawei, Meng Xiaoli, College Teachers Information Literacy State and Cultivating Strategy under Informatization Environment [J]. The Modern Education Journal, 2008, (09) 